\title{
MINAT BACA ANAK-ANAK DI KAMPOENG BACA KABUPATEN JEMBER
}

\author{
Ony Dina Maharani ${ }^{1}$, Kisyani Laksono ${ }^{2}$, Wahyu Sukartiningsih ${ }^{3}$ \\ email: onymaharani@gmail.com \\ Pendidikan Dasar Pascasarjana Universitas Negeri Surabaya
}

\begin{abstract}
Abstrak
Membaca menjadi topik penting yang menyita banyak perhatian masyarakat dunia. Kualitas membaca menentukan keberadapan suatu bangsa. Bangsa yang memiliki kualitas membaca rendah akan mengalami keterbelakangan dan ketertinggalan. Hal ini dapat diatasi dengan peningkatan minat dan kebiasaan membaca. Pola asuh orang tua dan keadaan situasional menjadi faktor penentu tumbuhnya kebiasaan tersebut. Tujuan khusus dari penelitian ini adalah untuk mengetahui faktor dasar timbulnya kebiasaan membaca. Data dikumpulkan menggunakan observasi, wawancara, dan catatan lapangan. Hasil penelitian menunjukkan bahwa faktor dasar yang membentuk kebiasaan baca ada faktor situasional dan pola asuh orang tua. Hasil penelitian juga menunjukkan bahwa kebiasaan membaca tidak berpengaruh signifikan terhadap kemampuan membaca.
\end{abstract}

Kata kunci: kebiasaan membaca, anak-anak, faktor membaca.

\begin{abstract}
Reading is an important topic that takes a lot of attention from the world community. Quality of reading determines the confrontation of a nation. Nations that have low reading quality will experience backwardness. This can be overcome by increasing interest and reading habits. Parenting patterns and situational circumstances become the determining factor of the growth of the habit. The specific purpose of this research is to know the basic factors of reading habit. Data were collected using observations, interviews, and field notes. The results showed that the basic factors that shape reading habits are situational factors and parenting patterns. The results also indicate that reading habits have no significant effect on reading ability.
\end{abstract}

Keywords: reading habit, children, reading factor.

\section{PENDAHULUAN}

Rendahnya minat baca masih menjadi perkerjaan rumah yang belum terselesaikan hingga saat ini. Berbagai program telah dilakukan untuk menemukan solusi terbaik. Hal ini disebabkan minat membaca tidak selalu berada pada level yang tinggi. Berbagai situasi turut memberi pengaruh. Memberikan buku yang tidak sesuai dengan usia anak atau memaksakan anak membaca buku yang tidak diminati, secara langsung dapat berpengaruh terhadap suasana hati anak tersebut. Kondisi ini akan semakin kurang menguntungkan apabila ditinjau dari tuntutan dan tanggung jawab untuk menjadikan buku sebagai bagian dari proses kebutuhan belajar di sekolah.

Minat bukan sesuatu yang dimiliki oleh seseorang begitu saja. Minat dan tumbuh dan dikembangkan (Singer, 1987). Minat tidak begitu saja ada dalam diri sesorang melainkan timbul karena adanya pengalaman dan usaha untuk mengembangkannya. Minat timbul karena daya tarik dari luar dan juga datang dari hati sanubari. Minat pada dasarnya adalah penerimaan suatu hubungan antara diri sendiri dengan sesuatu dari luar diri. Semakin kuat hubungan tersebut semakin kuat minatnya. Winkel (1994) menjelaskan bahwa minat adalah kecenderungan yang menetap untuk merasa tertarik pada bidang atau hal tertentu atau merasa senang berkecimpung dalam bidang tersebut. Minat dipengaruhi oleh perkembangan fisik, mental, kesiapan belajar, pengalaman, bahan bacaan, keadaal lingkungan, dan dukungan orang tua.

Membaca adalah serangkaian keterampilan yang meliputi kegiatan mengamati, memahami, dan memikirkan (Saddhono dan Slamet 2012). Minat membaca akan terwujud melalui proses belajar, berlatih, dan mengalami. Minat membaca selalu disertai keinginan dan usaha-usaha untuk membaca (Rahim 2008). Minat baca membutuhkan perhatian yang menyeluruh disertai perasaan senang terhadap kegiatan membaca (Wahadaniah dalam Ratnasari 2011). Minat baca yang dibangkitkan pada usia dini dapat dijadikan landasan bagi berkembangnya budaya baca di masa depan. Kualitas membaca anak sangat berpengaruh terhadap keberhasilannya 
dalam belajar dan dalam kehidupannya (Firdaus, 2016).

Indikator minat baca dibagi menjadi empat aspek, yakni (1) kesukaan yang indikatornya gairah dan inisiatif, (2) ketertarikan yang indikatornya responsif dan kesegeraan, (3) perhatian yang indikatornya konsentrasi dan ketelitian, (4) keterlibatan yang indikatornya kemauan dan keuletan (Safari 2003).

Pemerintah berupaya mencari solusi terbaik untuk meningkatkan minat dan kebiasaan membaca. Pada tahun 2015, pemerintah Indonesia menyikapi rendahnya membaca dengan lebih serius. Hal ini ditegaskan melalui Permendikbud No. 23 tahun 2015. Tersurat tentang pentingnya pembiasaan membaca buku non pelajaran secara rutin selama 15 menit sebelum pelajaran dimulai. Gerakan ini akrab disebut dengan Gerakan Literasi Sekolah atau GLS. Hal ini diharapkan dapat membuat siswa terbiasa membaca buku setiap hari sehingga terbentuklah budaya baca di sekolah.

Pada kenyataannya, berbagai program yang dilakukan belum memperoleh hasil maksimal. Kualitas membaca di Indonesia masih jauh di bawah negara-negara lain. Program for International Student Assesment (PISA) menyebutkan tingkat literasi Indonesia pada tahun 2015 masih berada pada urutan ke 64 dari 72 negara. Data terbaru dari Most Littered Nation In The World yang dilakukan oleh Central Connecticut State University pada maret 2016, menunjukkan bahwa Indonesia berada pada urutan ke 60 dari 61 negara anggota riset. Data statistik UNESCO 2012 menunjukkan indeks minat baca di Indonesia baru 0,001. Artinya tiap 1.000 penduduk hanya satu orang anak saja yang mempunyai minat baca. Menurut indeks pembangunan pendidikan UNESCO ini, Indonesia berada di nomor 69 dari 127 negara.

Masalah mendasar rendahnya minat dan kebiasaan membaca berhubungan dengan ketersediaan buku, faktor situasional dan pola asuh orang tua. Tidak semua anak mendapatkan buku yang berkualitas dan sesuai dengan usia. Faktor ekonomi atau rendahnya kesadaran orang tua untuk menyediakan buku bagi anak menyebabkan anak tidak mendapatkan buku yang dibutuhkan. Maharani (2016) menjelaskan minat membaca tidak dengan sendirinya dimiliki oleh seorang anak melainkan harus dibentuk. Perlu kerjasama antara orang tua, sekolah, dan lingkungan masyarakat untuk memberikan dukungan dan mengusahakan buku-buku bacaan yang berkualitas untuk anak (Wiryodijoyo 1989).

Rumusan masalah pada penelitian ini difokuskan pada bagaimanakah minat baca anak ditinjau dari aspek (1) kesukaan; (2) ketertarikan; (3) perhatian; (4) keterlibatan? dan apa saja faktor dasar minat baca? Tujuan khusus dari penelitian adalah mengetahui kualitas membaca dan menemukan faktor dasar minat baca. Secara umum hasil penelitian ini diharapkan dapat memberikan kontribusi sebagai upaya untuk memecahkan masalah rendahnya minat baca.

\section{KAJIAN PUSTAKA}

Membaca

Membaca merupakan kegiatan reseptif, suatu bentuk penyerapan yang aktif. Menurut Kamus Besar Bahasa Indonesia (2005:83) membaca adalah melihat serta memahami isi dari apa yang tertulis. Membaca merupakan suatu proses yang dilakukan serta dipergunakan oleh pembaca untuk memperoleh pesan yang hendak disampaikan penulis melalui media kata-kata atau bahasa tulis.

Membaca adalah suatu proses yang kompleks dan rumit. Kompleks berarti dalam proses membaca terlibat berbagai faktor internal dan faktor eksternal pembaca. Faktor internal berupa intelegensi, minat, sikap, bakat, motivasi, tujuan membaca, dan lain sebagainya. Faktor eksternal bisa dalam bentuk sarana membaca, latar belakang sosial dan ekonomi, dan tradisi membaca. Rumit artinya faktor eksternal dan internal saling berhubungan membentuk koordinasi yang rumit untuk menunjang pemahaman bacaan (Nurhadi, 2008).

\section{Minat Membaca}

Ebbers (2011) menjelaskan interst is described as a motivational force that involves the focused allocation of extra attention, leading to deeper processing, better comprehension, longer recall. I explain how a situational interest can become an individual interest and how interest is related to curiosity, self-efficacy and knowledge. Several ways to prompt interest are outlined and a sample survey is provided. Finally, I distinguish interest from other motivational variables such as choice, discussion and enjoyment.

Aspek minat baca anak menurut Safari (2003) sebagai berikut

a. Perasaan Senang 
Seorang siswa yang memiliki perasaan senang atau suka terhadap suatu mata pelajaran, maka siswa tersebut akan terus mempelajari ilmu yang disenanginya. Tidak ada perasaan terpaksa pada siswa untuk mempelajari bidang tersebut.

b. Ketertarikan Siswa

Berhubungan dengan daya gerak yang mendorong untuk cenderung merasa tertarik pada orang, benda, kegiatan atau bisa berupa pengalaman afektif yang dirangsang oleh kegiatan itu sendiri.

c. Perhatian Siswa

Perhatian merupakan konsentrasi atau aktivitas jiwa terhadap pengamatan dan pengertian, dengan mengesampingkan yang lain dari pada itu. Siswa yang memiliki minat pada objek tertentu, dengan sendirinya akan memperhatikan objek tersebut.

d. Keterlibatan Siswa

Ketertarikan seseorang akan suatu objek yang mengakibatkan orang tersebut senang dan tertarik untuk melakukan atau mengerjakan kegiatan dari objek tersebut.

Harris dan Sipay (Mujiati, 2001) menjelaskan bahwa minat baca dipengaruhi oleh dua faktor golongan, yaitu golongan faktor personal dan golongan institusional. Faktor personal adalah faktor yang berasal dari dalam diri anak itu sendiri. Berikut diantaranya.

a. Usia.

b. Jenis kelamin.

c. Intelegensi.

d. Kemampuan membaca.

e. Sikap.

f. Kebutuhan psikologis.

Faktor institusional yaitu faktor yang berasal dari luar individu itu sendiri. Berikut diantaranya.

a. Tersedianya buku-buku.

b. Status sosial ekonomi.

c. Pengaruh orang tua, teman sebaya dan pengajar.

\section{METODE}

Penelitian ini adalah penelitian deskriftif dengan menggunakan pendekatan kualitatif. Pengambilan data dilakukan sampai data jenuh. Proses kerja penelitian ini menggunakan perspektif emik, dengan mengutamakan pandangan dan pendirian subjek penelitian terhadap situasi yang dihadapinya. Desain penelitian ini menggunakan rancangan penelitian deskriptif. Metode deskriptif merupakan metode yang digunakan untuk memperoleh data dari penggambaran keadaan yang sebenarnya tanpa adanya perlakuan khusus kepada subjek penelitian. Lokasi penelitian dilakukan di salah satu daerah di Indonesia.

Teknik pengumpulan data melalui observasi, wawancara, dan catatan lapangan. Data dianalisis secara kualitatif kemudian diuraikan dalam bentuk deskriptif (Basrowi \& Suwandi, 2008). Penelitian dilakukan secara kompeten. Fenomena yang muncul dianalisis, ditafsirkan, dan ditarik kesimpulan.

Observasi dilakukan melalui pengamatan. Tiga komponen yang dapat diamati yaitu ruang (tempat), pelaku (aktor), dan kegiatan (aktivitas). Observasi pada penelitian ini dilakukan dengan cara hidup dan berada dekat dengan kegiatan subjek penelitian.

Tabel 1. Pedoman Observasi

\begin{tabular}{|c|c|c|}
\hline Faktor & $\begin{array}{l}\text { Aspek } \\
\text { yang } \\
\text { Diteliti }\end{array}$ & Deskripsi \\
\hline \multirow[t]{5}{*}{ Personal } & Usia & Usia dari anak \\
\hline & $\begin{array}{l}\text { Jenis } \\
\text { kelamin }\end{array}$ & $\begin{array}{l}\text { Dibedakan menjadi dua, } \\
\text { laki-laki dan perempuan }\end{array}$ \\
\hline & $\begin{array}{l}\text { Intelegen } \\
\text { si }\end{array}$ & $\begin{array}{l}\text { Berhubungan dengan } \\
\text { kemampuan } \\
\text { anak }\end{array}$ \\
\hline & $\begin{array}{l}\text { Kemauan } \\
\text { membaca }\end{array}$ & $\begin{array}{l}\text { Apabila disediakan buku, } \\
\text { anak akan bersemangat } \\
\text { untuk membaca buku } \\
\text { tersebut atau tidak. }\end{array}$ \\
\hline & Sikap & $\begin{array}{l}\text { Berhubungan pula } \\
\text { dengan bahan bacaan } \\
\text { yang dipilih anak. } \\
\text { Apabila disediakan buku, } \\
\text { anak akan segera } \\
\text { membaca buku tersebut } \\
\text { atau tidak }\end{array}$ \\
\hline \multirow[t]{5}{*}{$\begin{array}{l}\text { Institusion } \\
\text { al }\end{array}$} & $\begin{array}{l}\text { Ketersedi } \\
\text { aan buku }\end{array}$ & $\begin{array}{lcr}\text { Jumlah dan jenis buku } \\
\text { yang tersedia di }\end{array}$ \\
\hline & & Kampoeng Batja \\
\hline & $\begin{array}{l}\text { Status } \\
\text { ekonomi }\end{array}$ & Golongan keluarga \\
\hline & $\begin{array}{l}\text { Pengaruh } \\
\text { orang tua } \\
\text { dan } \\
\text { teman }\end{array}$ & $\begin{array}{l}\text { Membaca karena diri } \\
\text { sendiri atau pengaruh } \\
\text { orang lain. Budaya } \\
\text { membaca di rumah dari } \\
\text { orang tua. }\end{array}$ \\
\hline & $\begin{array}{l}\text { Pengaruh } \\
\text { lingkung }\end{array}$ & $\begin{array}{l}\text { Situasi lingkungan yang } \\
\text { mendukung atau tidak }\end{array}$ \\
\hline
\end{tabular}


an

Analisis data melalui wawancara dilakukan dengan mengajukan pertanyaan-pertanyaan terbuka. Berikut merupakan tabel wawancara penelitian.

\begin{tabular}{|c|c|c|c|c|c|}
\hline $\mathbf{N}$ & Pertanyaan & & Kode & & \\
\hline $\mathbf{0}$ & & $\mathbf{A}$ & B & C & D \\
\hline 1 & $\begin{array}{l}\text { Apakah kamu } \quad \text { bisa } \\
\text { membaca? }\end{array}$ & Lancar & $\begin{array}{l}\text { Lancar tapi putus- } \\
\text { putus }\end{array}$ & Mengeja & $\begin{array}{l}\text { Tidak bisa } \\
\text { membaca dan } \\
\text { malas }\end{array}$ \\
\hline 2 & Apa kamu suka membaca? & Sangat suka & Suka & Kurang suka & Tidak suka \\
\hline 3 & $\begin{array}{l}\text { Apakah membaca termasuk } \\
\text { hobimu? }\end{array}$ & Hobi utama & $\begin{array}{l}\text { Hobi tapi bukan } \\
\text { yang utama }\end{array}$ & $\begin{array}{l}\text { Suka saja, } \\
\text { bukan hobi }\end{array}$ & $\begin{array}{c}\text { Tidak hobi } \\
\text { dan tidak suka }\end{array}$ \\
\hline 4 & $\begin{array}{l}\text { Buku mana yang paling } \\
\text { kamu suka? }\end{array}$ & $\begin{array}{c}\text { Buku cerita } \\
\text { tidak } \\
\text { bergambar dan } \\
\text { tidak berwarna }\end{array}$ & $\begin{array}{l}\text { Buku cerita tidak } \\
\text { bergambar dan } \\
\text { berwarna }\end{array}$ & $\begin{array}{l}\text { Buku cerita } \\
\text { bergambar dan } \\
\text { berwarna }\end{array}$ & $\begin{array}{l}\text { Buku } \\
\text { bergambar } \\
\text { saja }\end{array}$ \\
\hline 5 & $\begin{array}{l}\text { Apa kamu ingin langsung } \\
\text { membaca buku itu? }\end{array}$ & Iya. Langsung & $\begin{array}{l}\text { Iya, tapi nanti (pada } \\
\text { hari yang sama) }\end{array}$ & $\begin{array}{l}\text { Iya, tapi nanti } \\
\text { (pada hari } \\
\text { yang berbeda) }\end{array}$ & Tidak \\
\hline 6 & $\begin{array}{l}\text { Kamu tertarik membaca } \\
\text { buku lainnya? }\end{array}$ & Iya & $\begin{array}{l}\text { Iya, tapi nanti (pada } \\
\text { hari yang sama) }\end{array}$ & $\begin{array}{l}\text { Iya, tapi nanti } \\
\text { (pada hari } \\
\text { yang berbeda) }\end{array}$ & Tidak \\
\hline 7 & $\begin{array}{l}\text { Apakah kamu mau membaca } \\
\text { buku yang tidak berwarna } \\
\text { dan tidak gambar? }\end{array}$ & Iya & $\begin{array}{l}\text { Iya, tapi tidak } \\
\text { terlalu suka }\end{array}$ & $\begin{array}{l}\text { Tidak terlalu } \\
\text { suka }\end{array}$ & Tidak mau \\
\hline 8 & $\begin{array}{l}\text { Jika ada waktu luang, apa } \\
\text { kamu gunakan untuk } \\
\text { membaca? }\end{array}$ & Sangat setuju & Setuju & Kurang setuju & Tidak setuju \\
\hline 9 & $\begin{array}{l}\text { Berapa jam dalam sehari } \\
\text { biasanya kamu membaca } \\
\text { buku? }\end{array}$ & $120-180$ menit & $60-120$ menit & $<60$ & 15 menit \\
\hline 10 & $\begin{array}{l}\text { Buku jenis apa yang paling } \\
\text { kamu suka? }\end{array}$ & Ensiklopedia & $\begin{array}{l}\text { Buku cerita } \\
\text { dongeng }\end{array}$ & $\begin{array}{l}\text { Majalah atau } \\
\text { komik }\end{array}$ & $\begin{array}{l}\text { Tidak suka } \\
\text { buku }\end{array}$ \\
\hline 11 & $\begin{array}{l}\text { Apabila temanmu } \\
\text { mempunyai buku baru yang } \\
\text { kamu suka, apakah yang } \\
\text { akan kamu lakukan? }\end{array}$ & $\begin{array}{l}\text { Langsung } \\
\text { meminjam }\end{array}$ & $\begin{array}{l}\text { Menunggu teman } \\
\text { selesai membaca }\end{array}$ & $\begin{array}{l}\text { Menunggu } \\
\text { dipinjami }\end{array}$ & Tidak peduli \\
\hline 12 & $\begin{array}{l}\text { Bila kamu mendapat } \\
\text { Pekerjaan Rumah (PR) dari } \\
\text { sekolah dan kamu tidak } \\
\text { mempunyai buku, apakah } \\
\text { kamu akan pergi ke } \\
\text { perpustakaan Kampoeng } \\
\text { Batja? }\end{array}$ & $\begin{array}{l}\text { Iya, tanpa } \\
\text { ragu-ragu }\end{array}$ & $\begin{array}{l}\text { Iya, sedikit ragu- } \\
\text { ragu }\end{array}$ & & Tidak \\
\hline 13 & $\begin{array}{l}\text { Apakah menurutmu buku } \\
\text { adalah hal yang penting? }\end{array}$ & Sangat setuju & Setuju & Kurang setuju & Tidak setuju \\
\hline 14 & $\begin{array}{l}\text { Kalau punya uang lebih, } \\
\text { ingin beli apa? }\end{array}$ & Buku bacaan & Buku gambar & Mainan & Makanan \\
\hline 15 & $\begin{array}{l}\text { Apakah kamu akan langsung } \\
\text { membaca buku ketika diberi }\end{array}$ & Iya & $\begin{array}{l}\text { Iya, tapi nanti (pada } \\
\text { hari yang sama) }\end{array}$ & $\begin{array}{l}\text { Iya, tapi nanti } \\
\text { (pada hari }\end{array}$ & Tidak \\
\hline
\end{tabular}




\begin{tabular}{|c|c|c|c|c|c|}
\hline & buku baru? & & & yang berbeda) & \\
\hline 16 & $\begin{array}{l}\text { Berapa jumlah buku yang } \\
\text { kamu miliki di rumah, selain } \\
\text { buku sekolah? }\end{array}$ & $>15$ buku & $10-15$ buku & $5-10$ buku & $<5$ buku \\
\hline \multirow[t]{2}{*}{17} & $\begin{array}{l}\text { Apakah buku yang kamu } \\
\text { sukai pernah kamu pinjam } \\
\text { dari } \quad \text { perpustakaan }\end{array}$ & $>10$ kali & 5-10 kali & $<5$ kali & Tidak pernah \\
\hline & $\begin{array}{l}\text { Kampoeng Batja? } \\
\text { kali dalam samapa } \\
\text { terakhir? }\end{array}$ & & & & \\
\hline 18 & $\begin{array}{l}\text { Apakah buku-buku yang } \\
\text { disediakan di Kampoeng } \\
\text { Batja membuatmu tertarik? }\end{array}$ & Sangat tertarik & Tertarik & $\begin{array}{l}\text { Kurang } \\
\text { tertarik }\end{array}$ & Tidak tertarik \\
\hline 19 & $\begin{array}{l}\text { Jika kamu sedang membaca } \\
\text { buku tapi temanmu } \\
\text { mengajakmu bermain, } \\
\text { apakah kamu akan ikut } \\
\text { bermain? }\end{array}$ & Tidak & & & Iya \\
\hline 20 & $\begin{array}{l}\text { Apa kamu bisa menangkap } \\
\text { makna certa dari bacaan } \\
\text { tadi? }\end{array}$ & Bisa dan benar & $\begin{array}{l}\text { Bisa, tapi ada } \\
\text { sedikit kesalahan }\end{array}$ & $\begin{array}{l}\text { Bisa, tapi } \\
\text { banyak } \\
\text { kesalahan }\end{array}$ & Salah \\
\hline 21 & $\begin{array}{l}\text { Apa kamu bisa menceritakan } \\
\text { kembali isi cerita yang sudah } \\
\text { kamu baca? }\end{array}$ & Bisa dan benar & $\begin{array}{c}\text { Bisa, tapi ada } \\
\text { sedikit kesalahan }\end{array}$ & $\begin{array}{l}\text { Bisa, tapi } \\
\text { banyak } \\
\text { kesalahan }\end{array}$ & Salah \\
\hline 22 & $\begin{array}{l}\text { Apakah kamu pernah lupa } \\
\text { waktu saat membaca buku? }\end{array}$ & $\begin{array}{l}\text { Pernah dan } \\
\text { sering (lebih } \\
\text { dari tiga hari } \\
\text { dalam satu } \\
\text { minggu) }\end{array}$ & $\begin{array}{l}\text { Pernah tapi tidak } \\
\text { lebih dari tiga kali } \\
\text { dalam satu minggu }\end{array}$ & Pernah saja & Tidak pernah \\
\hline \multirow[t]{6}{*}{23} & $\begin{array}{l}\text { Buku } \quad(\ldots \ldots \ldots . . .) \quad \text { dapat } \\
\text { membuatmu tertarik sampai } \\
\text { hampir lupa waktu. }\end{array}$ & & & & \\
\hline & $\begin{array}{l}\text { a. Buku cerita rakyat dan } \\
\text { fabel }\end{array}$ & Sangat setuju & Setuju & Kurang setuju & Tidak setuju \\
\hline & b. Komik & Sangat setuju & Setuju & Kurang setuju & Tidak setuju \\
\hline & c. Buku sejarah pahlawan & Sangat setuju & Setuju & Kurang setuju & Tidak setuju \\
\hline & d. Buku pelajaran & Sangat setuju & Setuju & Kurang setuju & Tidak setuju \\
\hline & e. Majalah anak-anak & Sangat setuju & Setuju & Kurang setuju & Tidak setuju \\
\hline 24 & $\begin{array}{l}\text { Adakah buku lain yang } \\
\text { kamu suka selain buku anak- } \\
\text { anak? }\end{array}$ & $\begin{array}{l}\text { Suka semua } \\
\text { jenis buku }\end{array}$ & $\begin{array}{l}\text { Ada, asalkan } \\
\text { bergambar }\end{array}$ & $\begin{array}{l}\text { Ada, asalkan } \\
\text { bergambar dan } \\
\text { berwarna }\end{array}$ & Tidak ada \\
\hline 25 & $\begin{array}{l}\text { Datang ke Kampoeng Batja } \\
\text { untuk membaca buku? }\end{array}$ & Sangat setuju & Setuju & Kurang setuju & Tidak setuju \\
\hline 26 & $\begin{array}{lcr}\text { Seberapa } & \text { sering } & \text { kamu } \\
\text { membaca } & \text { buku } & \text { di } \\
\text { Kampoeng } & \text { Batja } & \text { dalam } \\
\text { seminggu? } & & \end{array}$ & $>5$ hari & 3-5 hari & $<3$ hari & $\begin{array}{l}\text { Seminggu } \\
\text { sekali }\end{array}$ \\
\hline 27 & $\begin{array}{l}\text { Apakah kamu } \\
\text { menerapkapkan hasil } \\
\text { bacaanmu ke dunia nyata? }\end{array}$ & Sangat sering & Sering & $\begin{array}{l}\text { Kadang- } \\
\text { kadang }\end{array}$ & Tidak pernah \\
\hline 28 & Memberi pendapat terhadap & Sangat sering & Sering & Kadang- & Tidak pernah \\
\hline
\end{tabular}




\begin{tabular}{lllccc}
\hline apa yang sudah dibaca? & & & & \\
29 & $\begin{array}{l}\text { Apakah kamu mengikuti } \\
\text { kegiatan keterampilan yang } \\
\text { diadakan Kampoeng Batja? }\end{array}$ & Sangat sering & Sering & $\begin{array}{c}\text { Kadang- } \\
\text { kadang }\end{array}$ & Tidak pernah \\
30 & Membaca karena keinginan? & Diri sendiri & Ada tugas dari & Dekolah & Dipaksa orang \\
tua & Tidak mau \\
31 & $\begin{array}{l}\text { Apakah di sekolahmu ada } \\
\text { peraturan yang mewajibkan } \\
\text { membaca buku selama 15 } \\
\text { menit sebelum pembelajaran } \\
\text { di mulai? }\end{array}$ & Setiap hari & Kadang-kadang & Tidak tau & Tidak \\
\hline
\end{tabular}

Jawaban yang diperoleh akan dicatat kemudian di input ke dalam rubrik kode. Rubrik berisi empat komponen kode, yaitu A dengan skor 4; B dengan skor 3; C dengan skor 2; dan D dengan skor 1. Skor yang diperoleh akan dikonversi untuk menentukan minat baca. Kriteria minat baca yaitu 4-3,6 adalah sangat berminat; 3,5-2,6 adalah berminat; 2,5-1,6 adalah kurang berminat;1,5-1,0 adalah tidak berminat.

Catatan lapangan ditulis berdasarkan apa yang didengar, dilihat, dialami, dan dipikirkan pada saat pengumpulan data. Catatan lapangan mirip buku harian. Pada catatan lapangan selalu berisi keterangan waktu dan tanggal.

\section{PEMBAHASAN}

\section{Minat Baca}

Pengambilan data dilakukan dengan memperhatikan aspek personal anak dan pengaruh situasional di lapangan. Responden berjumlah dua puluh orang yang diambil secara acak. Pertanyaanpertanyaan yang diajukan seputar: (1) lamanya waktu yang mereka habiskan untuk membaca buku dan menonton TV dalam hitungan menit, (2) buku yang dibaca akhir-akhir ini, (3) buku paling favorit, jenis buku, majalah ,dan film televisi yang disukai, (4) jumlah buku yang dimiliki dan judul buku ingin dimiliki, (5) hobi, (6) rasa ketertarikan dan kesukaan membaca, serta (7) tujuan membaca.

Pertanyaan-pertanyaan terbuka yang sudah diajukan kepada responden kemudian dicatat sesuai instrumen penelitian yang disiapkan sebelumnya. Instrumen penelitian dikembangkan sesuai kondisi lapangan. Urutan pertanyaan disesuaikan dengan karakteristik anak. Jawaban dari anak dicatat, kemudian dimasukkan ke dalam rubik kode sesuai kepentingan penelitian pada masing-masing aspek. Rubrik berisi empat komponen, yakni A, B, C, dan D. Data hasil penelitian kemudian disusun ke dalam kolom/rubuk secara sistematis untuk memudahkan pembaca.

Hasil penelitian yang telah dilakukan terhadap minat baca berdasarkan aspek kesukaan, ketertarikan, perhatian, dan keterlibatan, selanjutnya dikumpulkan dan disajikan secara klasikal pada diagram.
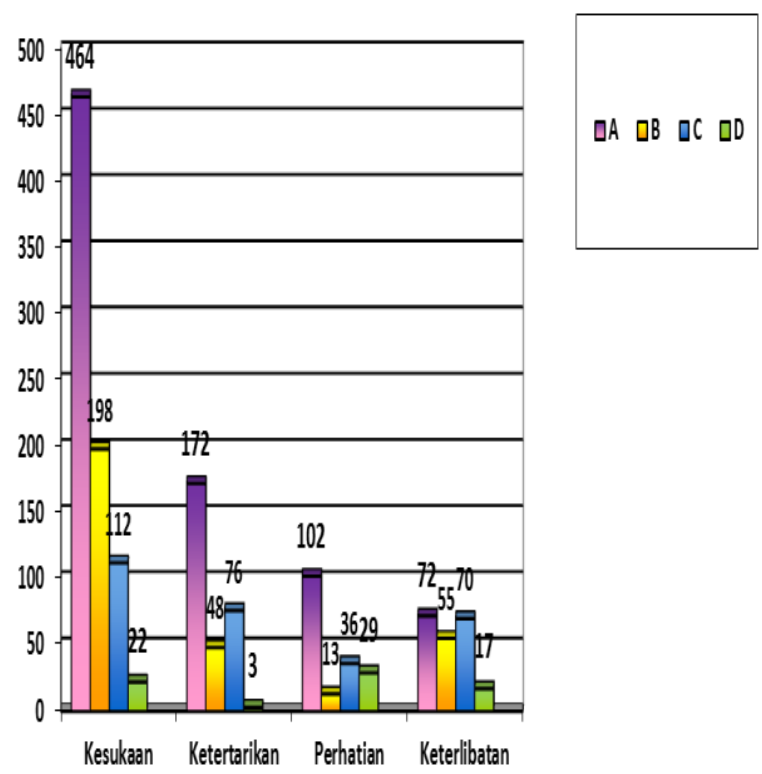

Gambar 1. Diagram Tingkat Membaca

Disimpulkan bahwa tingkat keberminatan anak terhadap buku atau bacaan dapat dikatakan berminat. Nampak pada aspek Kesukaan, Ketertarikan, dan Perhatian, anak-anak mempunyai minat yang tinggi, namun belum dapat dikatakan sangat tinggi. Anak-anak suka, berminat, dan mempunyai rasa perhatian terhadap buku, namun keterlibatannya masih kurang.

\section{Faktor Dasar Pengaruh Membaca}

Hasil penelitian di lapangan menunjukkan bahwa minat merujuk pada kesukaan. Minat tidak 
selalu berhubungan dengan kebutuhan. Minat berkaitan dengan keinginan hati seseorang. Rasa suka ini didapatkan dari pengalaman anak yang menyenangkan saat melakukan aktivitas membaca. Hasil analisis menunjukkan minat membaca tidak selalu berperan terhadap kemampuan membaca, begitu pula sebaliknya. Hal ini sangat menarik dan berbeda dengan penelitian sebelum-sebelumnya. Namun ada satu penelitian yang menemukan hasil yang sama. Hasil penelitian yang dilakukan Eidswick (2009) menunjukkan bahwa minat membaca tidak selalu berpengaruh terhadap kemampuan membaca.

Penelitian yang dilakukan Paul (2008) menunjukkan bahwa motifasi berperan penting pada meningkatnya minat anak dalam membaca. Penelitian ini menunjukkan hal yang berbeda. Hasil penelitian menunjukkan bahwa minat anak-anak menitikberatkan pada faktor-faktor situasional yang mempengaruhi minat membaca itu sendiri. Misalnya, jenis buku atau bahan bacaan, stimulus visual seperti objek atau gambar yang dilihat, faktor lingkungan, termasuk teman, dan pendamping belajar/membaca. Artinya, minat juga dipengaruhi oleh faktor-faktor dari luar individu. Hasil penelitian Eidswick (2009) menjelaskan bahwa minat dipengaruhi oleh faktor situasional, seperti jenis buku dan tempat membaca. Middleton (2011) pada penelitiannya juga menunjukkan bahwa minat membaca dipengaruhi oleh faktor situsional, salah satunya adalah lingkungan.

Buku cerita bergambar menjadi buku yang paling banyak diminati. Respon anak lebih besar terhadap jenis buku dengan tampilan yang menarik. Penelitian kali ini menemukan bahwa penyajian buku yang menarik, teks bacaan yang padat, terdapat gambar yang nyata, dekat dengan kehidupan nyata anak, dan dapat menimbulkan respon yang lebih baik dibandingkan buku yang hanya berisi tulisan saja. Tidak banyak anak yang memiliki ketertarikan terhadap buku-buku dan bahan bacaan yang berhubungan dengan kegiatan akademik di sekolah maupun buku-buku jenis lainnya yang cukup tinggi tingkat pemahamannya. Hal ini disebabkan kualitas buku mulai dari isi, bahasa, penyajian, dan kegrafikan buku yang kurang menarik. Seperti yang dijelaskan oleh Schraw\&Moshman (1995) bahwa karakteristik teks yang kemungkinan berkaitan dengan minat yang tinggi antara lain mudah dipahami, teks yang padat, ada penggambaran yang terkesan hidup, melibatkan pembacanya, menimbulkan berbagai reaksi emosi dan membutuhkan pengetahuan sebelumnya.

Pemilihan topik dalam cerita, amanat, karakter tokoh, harus sangat diperhatikan dan disesuaikan dengan usia anak. Isi dan alur yang menarik menyebabkan anak berminat terhadap bacaan tersebut. Apabila anak berminat dalam membaca maka perhatian yang dicurahkan lebih banyak dan usaha yang dilakukan lebih keras untuk memahami isi bacaan sehingga menghasilkan pemahaman membaca yang baik. Hal inilah yang kemudian menyebabkan sulitnya membedakan kemampuan membaca anak yang sebenarnya, maka diperlukan analisis yang mendalam. Isi bacaan yang kurang menarik (tidak diminati) lebih dipercaya dapat digunakan untuk membedakan antara anak berkemampuan membaca tinggi dengan anak/responden yang kurang mampu membaca.

Pola asuh orang tua memberikan dukungan besar pada keadaan ini. hasil penelitian Khairuddin (2013) menjelaskan bahwa pola asuh orang tua kepada anak merupakan faktor penentu minat baca. Faktor-faktor yang mempengaruhi minat baca salah satunya adalah keluarga. Secara general, orang tua dengan tingkat pendidikan rendah dan ekonomi yang kurang baik, berpotensi besar membuat minat baca anak rendah (Soeatminah 1991). Keluarga yang mempunyai kebiasaan dan kegemaran membaca akan memberikan pengaruh besar terhadap minat baca anak. dijelaskan bahwa kebiasaan membaca perlu ditumbuhkan dan ditingkatkan dari sejak kecil. Orang tua yang menyisihkan waktu untuk membaca dengan anak, memberikan permulaan yang baik untuk memahami literasi merupakan contoh yang ideal untuk mencapai prestasi pendidikan. Banyak penelitian yang menunjukkan anak yang berhasil mencapai prestasi literasi di sekolah biasanya datang dari lingkungan rumah yang menyediakan buku, dan orang tua mempunyai kesempatan untuk membaca dengan anak, serta melihat orang tua dan saudaranya melakukan aktivitas membaca.

Sedangkan penelitian yang dilakuakan Geske dan Ozola (2008) menunjukkan bahwa status ekonomi dan tingkat pendidikan orang tua yang rendah menyebabkan rendah pula minat baca seorang anak, namun hasil penelitian menunjukkan hasil yang sedikit berbeda. Minat membaca anak justru tumbuh dari dalam dirinya sendiri. 


\section{KESIMPULAN}

Dari hasil analisis disimpulkan bahwa kualitas membaca anak berada pada tingkat keberminatan dengan skor penilaian kinerja sebanyak 2,9. Minat dan kebiasaan membaca tidak dibawa sejak lahir melainkan diperoleh setelah ada interaksi terhadap suatu bahan bacaan. Membaca bahan bacaan, baik itu surat kabar, buku- buku pelajaran, atau buku-buku bacaan merupakan hal penting untuk mendisiplinkan diri agar rajin membaca. Beberapa faktor dasar yang menyebabkan tingginya minat baca adalah ketersediaan dan jenis buku, faktor situasional, dan faktor orang tua anak. Orang tua yang baik adalah orang tua yang melakukan upaya untuk menumbuhkan rasa cinta anak terhadap dunia membaca.

\section{Daftar Pustaka}

Basrowi \& Suwandi. (2008). Memahami Penelitian Kualitatif. Jakarta: Rineka Cipta.

Eidswick, J. (2009). The Influence of Interest on Reading Comprehension in EFL Students. Annual Research Report of the Language Center, 12, 25-38. Kwansei Gakuin University.

Firdaus, Ardiyansah Yuliniar (2016). Kompetensi Ideal Pendidik Untuk Menciptakan Masyarakat Literat di Sekolah Dasar. Simposium Guru dan Tenaga Kependidikan dilaksanakan tanggal 26 November di Bogor-Jawa Barat. Jakarta: Direktorat Jenderal Guru dan Tenaga Kependidikan (KEMENDIKBUD).

Geske, Andrejs \& Ozola, Antra. (2008). Factors Influencing Reading Literacy at the Primary School Level. Problems of Education in the 21st Century, Vol 6. University of Latvia, Riga, Latvia.

Khairuddin, Zurina. (2013). A Study of Students' Reading Interests in a Second Language. International Education Studies; Vol. 6, No. 11; 2013. Universiti Sultan Zainal Abidin, Malaysia.

Maharani, Ony Dina. (2016). The Children's Reading Interest and Reading Skill in "Kampoeng Batja" Jember Regency. The $1^{\text {th }}$
International Coference of Primary Education.

Middleton, Margaret Elizabeth. (2011). Reading Motivation and Reading Comprehension. Thesis. The Ohio State University.

Nurhadi. 2008. Membaca Cepat dan Efektif. Bandung: Sinar Baru Algensindo.

OECD. (2004a). Learning for tomorrow's world: First results from PISA 2003. Paris, France: OECD.

Paul, Morgan. (2008). Does Early Reading Failure Decrease Children's Reading Motivation?. Journal of Learning Disabilities, 387-404.

Permendikbud No. 23 tahun 2015 tentag Pertumbuhan Budi Pekerti

Rahim, Faridah. 2008. Pengajaran Membaca di Sekolah Dasar. Jakarta: Bumi Aksara.

Ratnasari, Yunita. 2011. Pengaruh Pergaulan Teman Sebaya terhadap Minat Baca Siswa Kelas V SD Negeri Bojongsari Purbalingga. Skripsi: FIP Universitas Yogyakarta. (diganti dr rujukan luar negeri)

Safari. (2003). Indikator Minat Belajar. Jakarta: Rineka Cipta.

Saddono, K dan Slamet, St. Y. (2012). Meningkatkan Keterampilan Berbahasa indonesia. Bandung: Karya Putra Darwati.

Scrhaw, G \& Moshman, D. (1995). Metacognitive Theories. Educational Psychology Review. 7 (4), 351-371.

Singer, Kurt. (1987). Membangun Hasrat Belajar di Sekolah. bandung: Remaja Karya, p.93.

Soeatminah. (1991). Perpustakaan Kepustakawanan dan Pustakawan. Yogyakarta: Kanisius.

Winkel, WS. (1989). Psikolog Pengajaran. Jakarta: Raja Grafindo Persada, p. 30 
